\title{
Camptothecin induced mitochondrial dysfunction leading to programmed cell death in unicellular hemoflagellate Leishmania donovani
}

\author{
N Sen ${ }^{1}$, BB Das ${ }^{1}$, A Ganguly ${ }^{1}$, T Mukherjee ${ }^{1}$, G Tripathi ${ }^{2}$, \\ S Bandyopadhyay ${ }^{3}$, S Rakshit ${ }^{3}$, T Sen ${ }^{4}$ and HK Majumder ${ }^{\star, 1}$ \\ ${ }^{1}$ Division of Infectious Diseases, Indian Institute of Chemical Biology. 4, Raja \\ SC Mullick Road, Kolkata 700 032, India \\ 2 Division of Cellular Physiology, Indian Institute of Chemical Biology. 4, Raja SC \\ Mullick Road, Kolkata 700 032, India \\ 3 Division of Immunology, Indian Institute of Chemical Biology. 4, Raja SC \\ Mullick Road, Kolkata 700 032, India \\ 4 Department of Biochemistry, Dr. BC Roy Postgraduate Institute of Basic \\ Medical Sciences, Calcutta University, 244,B, AJC Bose Road, Kolkata 700 \\ 020, India \\ * Corresponding author: HK Majumder, Division of Infectious Diseases, Indian \\ Institute of Chemical Biology. 4, Raja SC Mullick Road, Kolkata 700 032, India. \\ Tel: + 91-33-2412-3207; Fax: + 91-33-2473-5197; \\ E-mail: hkmajumder@iicb.res.in
}

Received 13.11.03; revised 10.2.04; accepted 13.2.04; published online 30.4.04 Edited by $S$ Nagata

\begin{abstract}
The parasites of the order kinetoplastidae including Leishmania spp. emerge from most ancient phylogenic branches of unicellular eukaryotic lineages. In their life cycle, topoisomerase I plays a significant role in carrying out vital cellular processes. Camptothecin (CPT), an inhibitor of DNA topoisomerase $I$, induces programmed cell death (PCD) both in the amastigotes and promastigotes form of $L$. donovani parasites. CPT-induced cellular dysfunction in $L$. donovani promastigotes is characterized by several cytoplasmic and nuclear features of apoptosis. CPT inhibits cellular respiration that results in mitochondrial hyperpolarization taking place by oligomycin-sensitive F0-F1 ATPase-like protein in leishmanial cells. During the early phase of activation, there is an increase in reactive oxygen species (ROS) inside cells, which causes subsequent elevation in the level of lipid peroxidation and decrease in reducing equivalents like GSH. Endogenous ROS formation and lipid peroxidation cause eventual loss of mitochondrial membrane potential. Furthermore, cytochrome $c$ is released into the cytosol in a manner independent of involvement of CED3/CPP32 group of proteases and unlike mammalian cells it is insensitive to cyclosporin $A$. These events are followed by activation of both CED3/CPP32 and ICE group of proteases in PCD of Leishmania. Taken together, our study indicates that different biochemical events leading to apoptosis in leishmanial cells provide information that could be exploited to develop newer potential therapeutic targets.

Cell Death and Differentiation (2004) 11, 924-936.

doi:10.1038/sj.cdd. 4401435

Published online 30 April 2004
\end{abstract}

Keywords: apoptosis; Leishmania; DNA topoisomerase I; camptothecin; mitochondria

\begin{abstract}
Abbreviations: CPT, camptothecin; $\Delta \psi_{\mathrm{m}}$, mitochondrial transmembrane potential; NAC, $N$-acetyl-cysteine; SB, sodium benzoate; BHT, butylated hydroxy toluene; TUNEL, terminal deoxynucleotidyltransferase enzyme mediated dUTP end labelling; CCCP, carbonyl cyanide $m$-chlorophenylhydrazone; PTP, permeability transition pore; $M C B$, monochlorobimane; VAD-fmk, Val-Ala-Asp-fluoromethyl ketone; LEHD-AMC, Leu-Glu-HisAsp-7-amino-4-methyl coumarin; DEVD-AFC, Asp-Glu-ValAsp-7-amino-4-trifluoromethyl coumarin; PCD, programmed cell death
\end{abstract}

\section{Introduction}

DNA topoisomerases are ubiquitous enzymes that catalyse the interconversion of topological isomers of DNA molecules. They act by sequential breakage and reunion of either one strand (topo I) or both the strands of DNA (topo II) and are involved in many vital processes, for example, replication, transcription, recombination, integration and chromosomal segregation. ${ }^{1}$ These enzymes are essential not only for the orderly synthesis of nucleic acids but also they are the molecular targets for numerous clinically important antibacterial and antitumour agents like fluoroquinolone, etoposide and camptothecin (CPT), etc. ${ }^{2,3}$

CPT, a class I DNA topoisomerase inhibitor that stabilizes topo I-DNA covalent complex and blocks subsequent rejoining of the DNA break, is an effective antitumour drug. ${ }^{4}$ In cultured cells, CPT inhibits both DNA and RNA synthesis, ${ }^{5}$ arrests cells in the G2 phase of the cell cycle, ${ }^{6}$ stimulates sister chromatid exchanges and chromosomal aberrations, ${ }^{7}$ elevates p53 levels, ${ }^{8}$ induces multiubiquitination and degradation of topo $\mathrm{I}^{9}$ and activates signal transduction molecules such as proto-oncogenes and NF-k $\beta .{ }^{10}$ All these activities ultimately lead to apoptosis.

Apoptosis is a programmed cell death (PCD), characterized by a series of distinct morphological and biochemical changes $^{11}$ and plays vital roles in normal cell turnover and development in multicellular as well as in unicellular organisms. Both in multicellular and unicellular organisms, the mitochondrion is an important cellular source for the generation of reactive oxygen species (ROS) inside cells, which serve as inducing signals for apoptosis. ${ }^{12}$ ROS production during the early phase of apoptosis is regulated by increased synthesis of reducing equivalents like GSH. ${ }^{13}$ Also, the permeabilization of mitochondrial membrane causes the release of proapoptotic proteins including cytochrome $c^{14}$ into the cytosol. It has been reported that changes in the lipid content due to oxidative damage ${ }^{15}$ triggers the release of 
cytochrome $c$ from mitochondria in the apoptotic process. Cytochrome $c$ serves as the key regulator of apoptosis because once it is blocked from the intermembrane space, the cell is irreversibly committed to death. In particular, the release of mitochondrial cytochrome $c$ into the cytoplasm is thought to be a critical step in the activation of different caspases like caspases 9 and $3 .^{16}$ At this stage, numerous different signalling pathways converge through which multiple downstream substrates are cleaved. The importance of an optimum mitochondrial transmembrane potential $\left(\Delta \psi_{\mathrm{m}}\right)$ in cell survival has been recognized not only in mammals but also in yeast ${ }^{17}$ and in protozoan parasites ${ }^{18,19}$ as well.

Leishmania has a digenic life cycle residing as flagellated extracellular promastigotes in the gut of insect vector and as blood stream promastigotes in the mammalian host where they infect macrophages and transform into nonflagellated amastigotes. ${ }^{20}$ With the spread of human immunodeficiency virus and general low standards of public hygiene, the Leishmania parasites pose a much greater threat than before, particularly in developing countries. To make the situation even worse some parasite strains also have developed resistance against the classical antimonial drug, like sodium stibogluconate. The second line of drugs, amphotericin B and pentamidine, although used clinically, are very toxic. ${ }^{21}$ Therefore, the characterization of cellular events associated with apoptosis or PCD is necessary to find out the cellular targets, which can be exploited in these protozoal cells. It was established earlier that DNA topoisomerases of Leishmania are targets for therapeutic agents. ${ }^{22} \mathrm{CPT}$, like other potential antileishmanial agents, has been shown to inhibit type I DNA topoisomerase of Leishmania donovani. ${ }^{23}$ However, it is still unclear how the stabilization of topo I-DNA covalent complex and subsequent induction of DNA strand breaks lead to cytotoxicity in leishmanial cells.

In the present study, we characterize the apoptotic pathway induced by CPT in unicellular organism $L$. donovani, which shares many features common to metazoan apoptosis, such as nuclear condensation, DNA fragmentation and cell shrinkage. We also identify the signals, downstream of topoisomerase I inhibition and upstream of caspase-like protease activation. We show that F0-F1 ATPase-like protein in leishmanial cells is responsible for the hyperpolarization of mitochondrial membrane potential, which precedes the formation of ROS inside cells. Oxidative stress-induced mitochondrial depolarization is an irreversible event in apoptosis-like death in $L$. donovani promastigotes. Loss of mitochondrial membrane potential causes the release of cytochrome $c$ into the cytosol, which leads to the activation of both ICE and CED3/CPP32 group of proteases inside cells. Our results provide the first insight into the mechanistic pathway of apoptosis in leishmanial cells where mitochondriaand caspase-like proteases play a central role during treatment with CPT.

\section{Results}

\section{CPT induces apoptotic cell death but does not induce dyskinetoplastidy}

L. donovani AG83 promastigotes $\left(2.5 \times 10^{6} \mathrm{cells} / \mathrm{ml}\right)$ were incubated with three different concentrations of CPT for $16 \mathrm{~h}$, following which the numbers of live promastigotes were counted by trypan blue exclusion method. After $4 \mathrm{~h}, 65 \%$ growth was inhibited by $5 \mu \mathrm{M}$ CPT and $95 \%$ growth was inhibited after $6 \mathrm{~h}$, which was comparable to the inhibition achieved by $10 \mu \mathrm{M}$ CPT after $4 \mathrm{~h}$. With $5 \mu \mathrm{M}$ CPT, a meager $5 \%$ parasite population survived after $6 \mathrm{~h}$ incubation (Figure 1A). Consistent with this result it was observed that after $6 \mathrm{~h}$ treatment with $5 \mu \mathrm{M}$, CPT growth of $L$. major, $L$. tropica and $L$. amazonensis was inhibited to the extent of 90 , 87 and $91 \%$, respectively (Figure 1B).

Electron microscopic studies on the ultrastructure of CPTtreated $L$. donovani promastigotes show that CPT induced certain morphological changes, which were the sign of PCD. The flagellated promastigotes become round shaped with an increase in vacuoles and lipid bodies. Nuclei from control promastigotes displayed a prominent central or slightly eccentrically localized nucleolus, while chromatin was usually distributed peripherally beneath the nuclear membrane (Figure $1 \mathrm{C}(\mathrm{a})$ ). However, in most of the CPT-treated cells condensed, irregular, crescentic or bead-like marginated chromatin and a fragmented nucleus with condensed cytoplasm were observed (Figure 1C(b)). These drug-treated cells also lost the specialized membrane structures, but the integrity of the plasma membrane was apparently maintained. At the late stage of apoptosis, the plasma membrane blebs and pinches off to form apoptotic bodies (Figure $1 \mathrm{C}(\mathrm{c})$ ). During apoptosis, a dilation of mitochondrial matrix occurred, leading to the destruction of the internal mitochondrial structure. CPT-treated mitochondria appeared swollen, without the typical cristae structure, but having a well-defined membrane around them. In contrast, when the cells were treated with CPT plus Val-Ala-Asp-fluoromethyl ketone (VAD-fmk), cells displayed condensed chromatin along with nuclear-membrane-like control cells (Figure $1 \mathrm{C}(\mathrm{d}))$.

Many DNA binding agents, for example, acriflavine and berenil, induce dyskinetoplastidy, a phenomenon where parasitic cells, though having mitochondrial membrane completely lack kDNA. ${ }^{24}$ Confocal microscopy of $L$. donovani AG83 promastigotes treated with CPT shows that CPT is incapable of inducing dyskinetoplastidy (Figure 1D(a)). Berenil-treated parasites are mostly dyskinetoplastic (Figure $1 \mathrm{D}(\mathrm{b}))$, whereas cells grown in media supplemented with $0.2 \%$ DMSO are completely healthy (Figure $1 \mathrm{D}(\mathrm{c})$ ).

\section{CPT inhibits oxygen consumption and increases the number of apoptotic cells}

Oxygen uptake was measured in the CPT-treated and untreated cells. L. donovani promastigotes consumes $\mathrm{O}_{2}$ at a rate of $80 \pm 10-\mathrm{nmol} / \mathrm{min} / \mathrm{mg}$ proteins, which remain unchanged up to $6.0 \mathrm{~h}$. The rate of $\mathrm{O}_{2}$ consumption decreases to $30 \%$ of the control value after treatment with CPT for $1 \mathrm{~h}$. After treatment with CPT for $4 \mathrm{~h}$, the respiration is inhibited to the extent of $81 \%$ (Figure 2a). CPT-induced inhibition of oxygen consumption was comparable to the increase in the number of apoptotic cells at different time periods (Figure $2 b$ ), as detected by an increase in the number of annexin $\mathrm{V}$ positive and PI negative cells. 

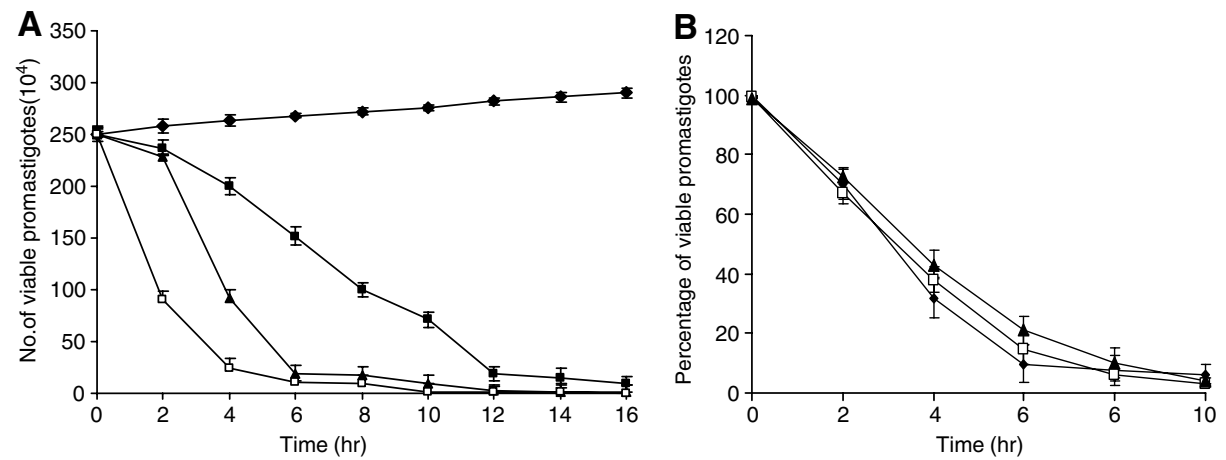

C
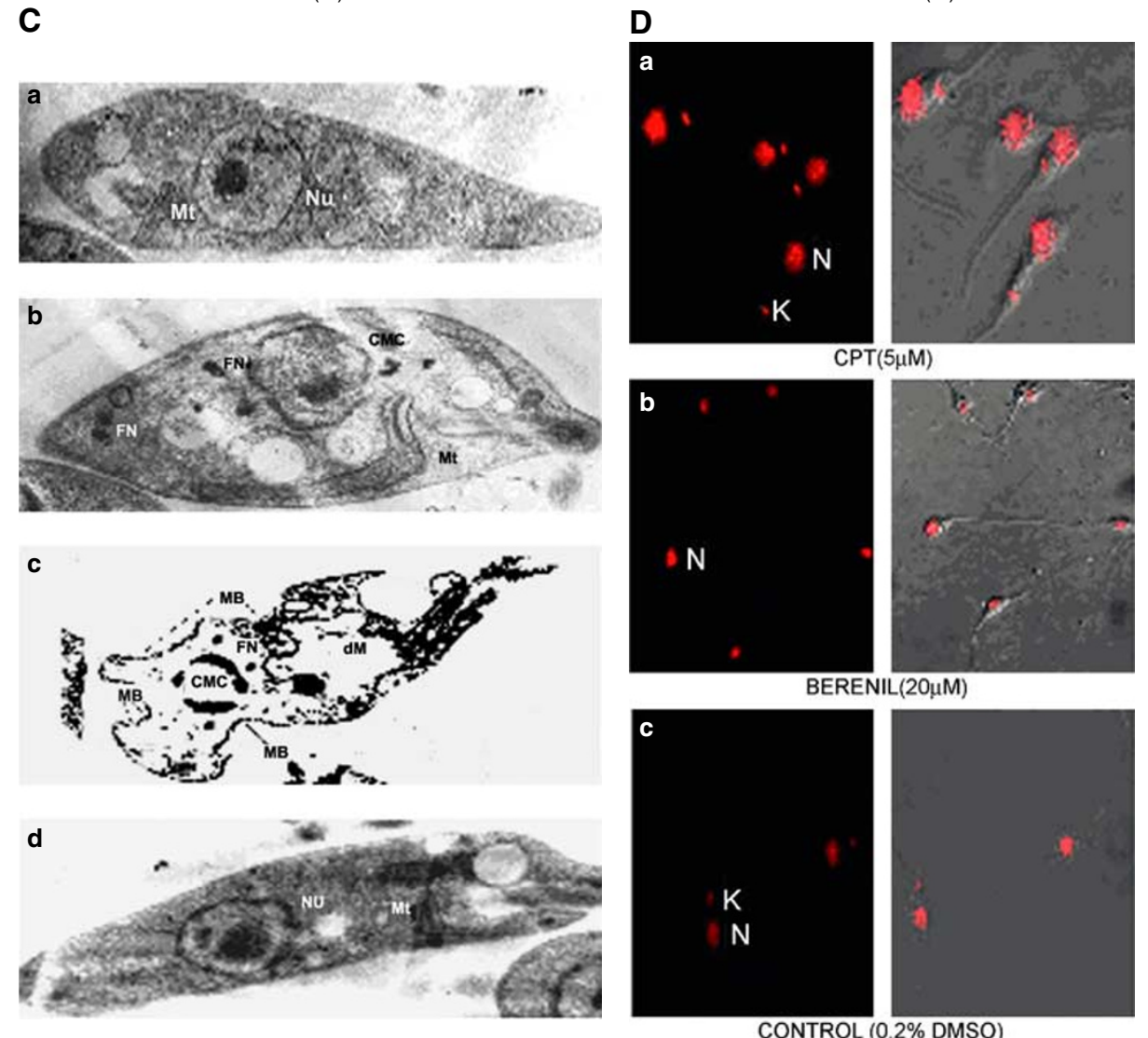

CONTROL (0.2\% DMSO)

Figure 1 Microscopic analysis of in vitro cytotoxicity of CPT and ultrastructural changes on cultured L. donovani promastigotes. (A) AG83 promastigote cells $\left(2.5 \times 10^{6}\right)$ were cultured for $16 \mathrm{~h}$ in M199 media supplemented with $10 \%$ fetal calf serum in the absence $(\bullet)$ and in the presence of $2 \mu \mathrm{M} \mathrm{CPT}(\mathbf{\square}), 5 \mu \mathrm{M} \mathrm{CPT}(\mathbf{\Delta})$ and $10 \mu \mathrm{M} \mathrm{CPT}(\square)$. No. of viable promastigotes was measured by trypan blue exclusion method. (B) L. major $(\mathbf{\Lambda})$, L. amazonensis $(\square)$ and $L$. tropica $(\bullet)$ promastigotes were also cultured in the presence of $5 \mu \mathrm{M} \mathrm{CPT}$ for $16 \mathrm{~h}$. Percentage of viable promastigotes was measured by trypan blue exclusion method. Data are expressed as percentage of live promastigotes and represent mean \pm S.D. from three independent experiments. (C) Electron microscopic analysis of $L$. donovani AG83 cells treated with $0.2 \%$ DMSO alone and $5 \mu \mathrm{M} \mathrm{CPT}$ for different time periods. Spur blocks were prepared as described in Materials and methods. (a) Control cells treated with $0.2 \%$ DMSO alone, (b) cells treated with $5 \mu \mathrm{M}$ CPT for $3 \mathrm{~h}$, (c) cells treated with $5 \mu \mathrm{M}$ CPT for $6 \mathrm{~h}$ and (d) cells treated with VAD-fmk plus $5 \mu \mathrm{M} \mathrm{CPT}$ for $6 \mathrm{~h}$. Magnification $\times 60000$. Nu $\rightarrow$ nucleus, $\mathrm{Mt} \rightarrow$ mitochondria, $\mathrm{CMC} \rightarrow$ condensed and marginated chromatin, $\mathrm{FN} \rightarrow$ fragmented nuclei, $\mathrm{dM} \rightarrow$ dilated matrix of mitochondria, $\mathrm{MB} \rightarrow$ membrane blebbing. (D) Confocal microscopy of $L$. donovani AG83 promastigotes. Parasites after incubation with (a) $5 \mu$ M CPT, (b) $20 \mu$ M berenil and (c) $0.2 \%$ DMSO alone were stained with ethidium bromide $(0.1 \mu \mathrm{g} / \mathrm{ml})$ in $\times 1$ phosphate-buffered saline containing $10 \%$ glycerol. Left panels, fluorescence-labelled cells viewed with a Leica confocal microscope. Right panels, merged pictures of fluorescence and phase contrast microscope. Magnification $\times 100$. Pictures are representative from one of three similar studies. $\mathrm{N} \rightarrow$ nucleus, $\mathrm{K} \rightarrow$ kinetoplast

\section{Inhibition of oxygen consumption causes the formation of ROS inside cells}

When L. donovanipromastigotes were treated with CPT, ROS are generated inside cells. The formation of superoxide radicals inside cells is measured by the reduction of NBT to blue formazan by the cell lysates prepared as described in Materials and Methods. The level of superoxide radical in CPT-treated cells remains four-fold higher compared to the levels of control cells throughout the experiments (Figure 3a). To know whether the reduction of NBT is only due to the formation of superoxide radicals, $\mathrm{SOD}^{25}$ was added to each 

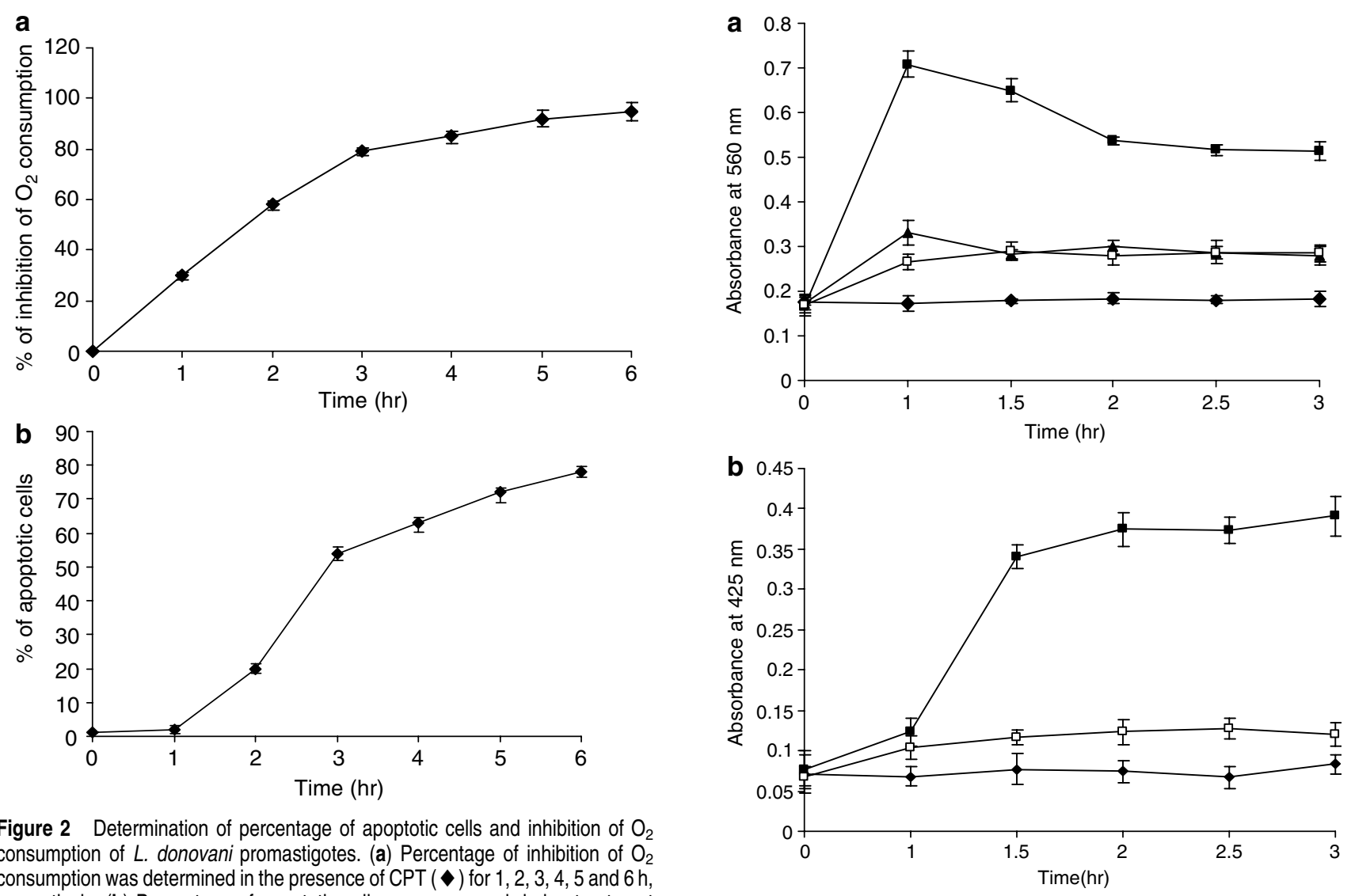

Figure 2 Determination of percentage of apoptotic cells and inhibition of $\mathrm{O}_{2}$ consumption of $L$. donovani promastigotes. (a) Percentage of inhibition of $\mathrm{O}_{2}$ consumption was determined in the presence of CPT $(\bullet)$ for $1,2,3,4,5$ and $6 \mathrm{~h}$, respectively. (b) Percentage of apoptotic cells was measured during treatment with $5 \mu \mathrm{M}$ of CPT ( ) for $1,2,3,4,5$ and $6 \mathrm{~h}$, respectively, by double staining with annexin V and PI as described in Materials and methods. Data are expressed as mean \pm S.D. of three independent experiments

reaction mixture prior to the addition of respective cell suspension. It was observed that the intensity of reduction of NBT to blue formazan by the lysates of CPT-treated cells is inhibited to about $45-55 \%$ at different times of incubation in the presence of SOD.

The level of hydroxyl radical is increased significantly after treatment of CPT for $1.5 \mathrm{~h}$ (Figure $3 \mathrm{~b}$ ). The generation of hydroxyl radicals in the CPT treated cells is detected by measuring the colour adducts formed due to the interaction of methane sulphinic acid with fast blue BB salt. Methane sulphinic acid is produced inside cells due to the interaction of DMSO and hydroxyl radicals formed by treatment with CPT. When $\mathrm{N}$-acetyl-cysteine (NAC) $(20 \mathrm{mM})$ was added to DMSO (2\%)-treated cells before the treatment of CPT, the level of hydroxyl radical is reduced compared to DMSO $(2 \%)$ - and CPT-treated cells.

\section{Oxidative stress causes depletion of the GSH level and increases the level of lipid peroxidation}

GSH is an important molecule for protecting kinetoplastids from ROS or toxic compounds, ${ }^{26}$ and may induce a loss of $\Delta \Psi_{\mathrm{m} .}{ }^{18}$ As shown in Figure $4 \mathrm{a}$, CPT causes $45 \%$ decrease in $\mathrm{GSH}$ level after $1.5 \mathrm{~h}$ and the effect is more pronounced after

\section{CPT induces mitochondrial hyperpolarization followed by depolarization}

The dissipation of $\Delta \psi_{\mathrm{m}}$ is a characteristic feature of apoptosis. ${ }^{27}$ To determine the changes in the $\Delta \psi_{\mathrm{m}}$, we used BD mitosensor reagent, which is a cationic dye that aggregates in the mitochondria of healthy cells. This aggregates fluoresce red at higher potential but at lower 

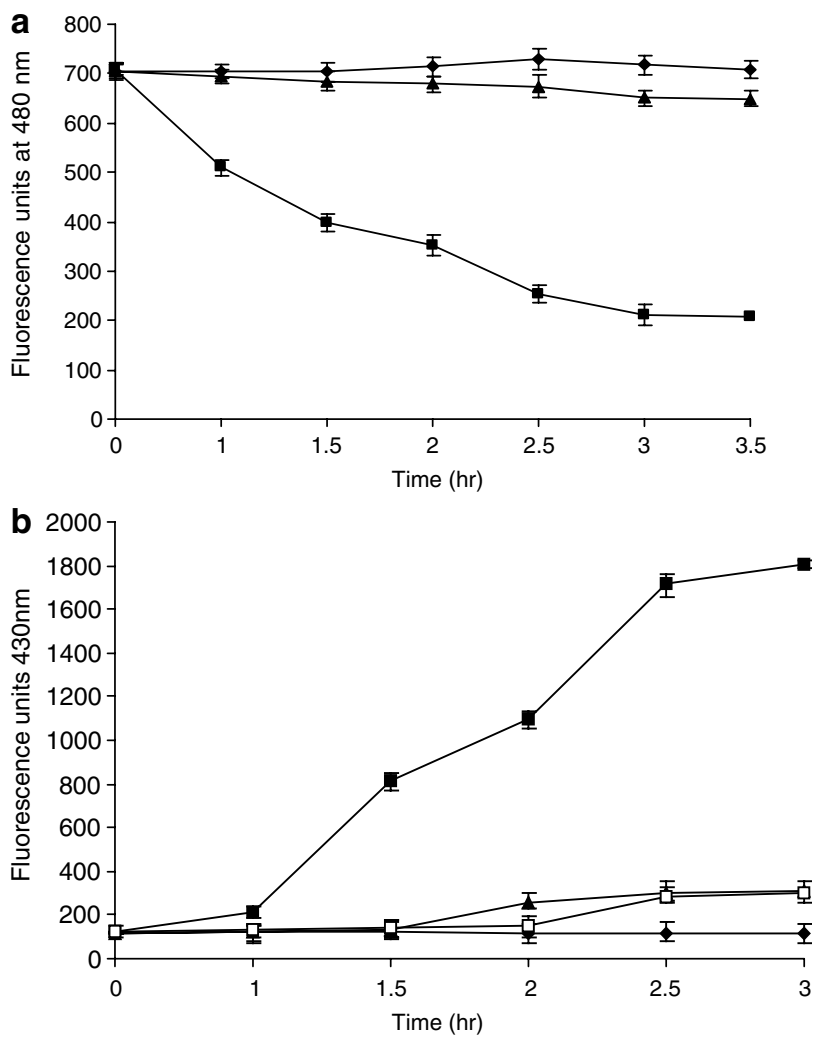

Figure 4 Determination of intracellular GSH level and level of lipid per oxidation during treatment with CPT. (a) Level of intracellular GSH in $L$. donovani promastigotes in treated and untreated cells. The intracellular GSH level was measured after treatment with CPT $(\boldsymbol{\square}), 0.2 \%$ DMSO alone $(\bullet)$ and with NAC (A) prior to treatment with CPT. (b). The level of fluorescent products of lipid peroxidation was measured after treatment with leishmanial cells containing $0.2 \%$ DMSO alone $(\bullet), 5 \mu \mathrm{M}$ of CPT $(\boldsymbol{\square})$, with NAC ( $\square$ ) and BHT $(\mathbf{\Delta})$ separately prior to treatment with CPT. Results are mean \pm S.D. from three independent experiments

potential this reagent cannot accumulate in the mitochondria and remains as monomers in the cytoplasm that fluoresces green. The ratio between red $(590 \mathrm{~nm})$ and green $(530 \mathrm{~nm})$ signals is a measure of $\Delta \psi_{\mathrm{m}}$. Through FACS analysis, we have measured the mean green fluorescence intensity, detected by FL- 1 channel. The ratio of $590 / 530$ was measured through spectrofluorometric analysis. As shown in Figure 5a, within $1 \mathrm{~h}$ treatment with $\mathrm{CPT}$, there was a shift in the distribution of cells towards the left side of FL-1 channel, suggesting an increased $\Delta \psi_{\mathrm{m}}$. This result is consistent with the increase in the ratio of 590/530 measured spectrofluorometrically. During mitochondrial hyperpolarization, the ratio of fluorescence intensity at $590 / 530$ becomes $8.8 \pm 0.97$ compared to $7.4 \pm 0.79$ of the control (Table 1). To investigate whether F0-F1ATPase-like protein in leishmanial cells is

Figure 5 Flow cytometry analysis of mitochondrial membrane potential. (a) Changes in mitochondrial membrane potential after treatment with $0.2 \%$ DMSO alone (control) and with $5 \mu \mathrm{M} \mathrm{CPT}$ for $1,1.5,2.5$ and $5 \mathrm{~h}$, respectively. FL1 channel indicates mean green fluorescence intensity. (b) Treatment with $5 \mu \mathrm{M}$ CPT in the presence and in the absence of oligomycin. (c) Treatment with uncoupling agent $\mathrm{CCCP}$, Caspase-like protease inhibitor VAD-fmk and different antioxidants like NAC, mannitol, SB and BHT prior to treatment with CPT
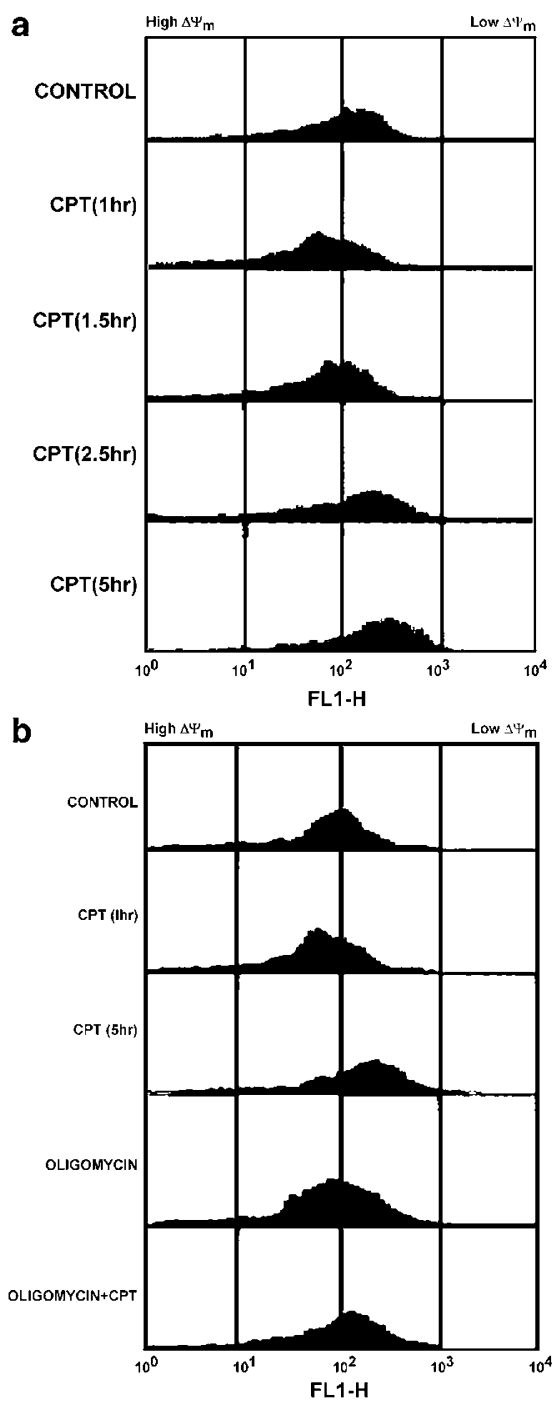

C

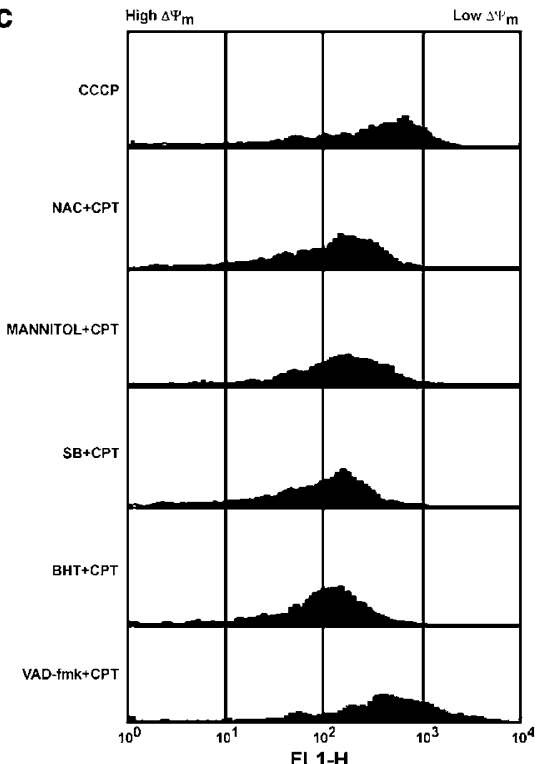


Table 1 Effects of treatments with CPT and different antioxidants on the mitochondrial membrane potential of $L$. donovani promastigotes as measured by fluorescence of $\mathrm{BD}$ mitosensor reagent

\begin{tabular}{lcc}
\hline Name of events & $\begin{array}{c}\text { Value of mean } \\
\text { green } \\
\text { fluorescence } \\
\text { intensity }\end{array}$ & Ratio of 590/530 \\
\hline Control $(0.2 \%$ & $130.42 \pm 4.91$ & $7.4 \pm 0.79$ \\
DMSO) & $71.96 \pm 5.26$ & $8.8 \pm 0.97$ \\
CPT $(1 \mathrm{~h})$ & $90.93 \pm 7.76$ & $8.2 \pm 0.76$ \\
CPT $(1.5 \mathrm{~h})$ & $255.1 \pm 8.21$ & $3.79 \pm 0.38$ \\
CPT $(2.5 \mathrm{~h})$ & $417.9 \pm 7.25$ & $2.52 \pm 0.76$ \\
CPT $(5.0 \mathrm{~h})$ & $522.8 \pm 5.39$ & $2.02 \pm 0.18$ \\
CCCP & $140.91 \pm 2.46$ & $7.52 \pm 0.42$ \\
NAC+CPT & $148.24 \pm 3.02$ & $7.62 \pm 0.66$ \\
Mannitol+CPT & $144.5 \pm 5.38$ & $7.58 \pm 0.21$ \\
SB+CPT & $142.36 \pm 4.12$ & $7.14 \pm 0.81$ \\
BHT+CPT & $389.4 \pm 8.7$ & $2.59 \pm 0.47$ \\
VAD-fmk+CPT & & \\
\hline
\end{tabular}

Table 2 Effects of treatments with CPT in the presence and absence of oligomycin on the mitochondrial membrane potential of $L$. donovani promastigotes as measured by fluorescence of BD mitosensor reagent

\begin{tabular}{lcr}
\hline Name of events & $\begin{array}{c}\text { Value of mean } \\
\text { green } \\
\text { fluorescence } \\
\text { intensity }\end{array}$ & Ratio of $\mathbf{5 9 0 / 5 3 0}$ \\
\hline Control & $132.64 \pm 3.34$ & $7.43 \pm 0.62$ \\
CPT $(1 \mathrm{~h})$ & $74.28 \pm 5.63$ & $8.9 \pm 0.51$ \\
CPT $(5 \mathrm{~h})$ & $421.71 \pm 3.78$ & $2.5 \pm 0.37$ \\
Oligomycin & $110.46 \pm 7.91$ & $7.92 \pm 0.28$ \\
Oligomycin+CPT & $138.38 \pm 4.67$ & $7.5 \pm 0.16$ \\
\hline
\end{tabular}

involved in the hyperpolarization of the mitochondria, experiments were carried out in the presence of oligomycin $(6 \mu \mathrm{M})$. It was observed that there is no hyperpolarization even after treatment with CPT to oligomycin-treated cells (Figure $5 b$ ). This is evident from the value of mean green fluorescence intensity as well as from the ratio of fluorescence units (Table 2). There is a significant fall (50\%) in $\Delta \psi_{\mathrm{m}}$ within the first $2.5 \mathrm{~h}$ treatment with CPT as compared with relative $\Delta \psi_{\mathrm{m}}$ observed at $0 \mathrm{~h}$. The loss of $\Delta \psi_{\mathrm{m}}$ is continued to the extent of $73 \%$ after $5 \mathrm{~h}$ treatment of CPT. The sensitivity of the BD mitosensor reagent to the change in mitochondrial membrane potential was tested by treating leishmanial cells with mitochondrial uncoupling agent carbonyl cyanide $m$-chlorophenylhydrazone (CCCP) $(1 \mu \mathrm{M})$. This causes total depolarization of mitochondrial membrane potential. When cells were treated with antioxidants like NAC $(20 \mathrm{mM})$, sodium benzoate (SB) $(20 \mathrm{mM})$ and Mannitol $(20 \mathrm{mM})$ or with lipid peroxidation inhibitor (BHT) at $20 \mathrm{mM}$ before the treatment with $\mathrm{CPT}$, loss of mitochondrial membrane potential is prevented. This was evidenced from the mean green fluorescence intensity that tends to become normal (Figure $5 \mathrm{c}$ ), and is also confirmed by the ratio of fluorescence intensity $(590: 530)$ represented in Table 1. However, treatment with CED-3/CPP32 group of protease inhibitor (VAD-fmk) prior to the treatment with CPT does not prevent the loss of mitochondrial membrane potential, indicating that this is not responsible for the mitochondrial membrane depolarization (Table 1).

\section{Loss of mitochondrial membrane potential causes release of cytochrome $c$}

Disruption of the outer mitochondrial membrane by apoptotic stimuli results in the release of the cytochrome $c$ into the cytoplasm where it initiates caspases activation and results in apoptosis. ${ }^{27-29}$ We have shown by Western blotting and confocal microscopy that CPT treatment causes cytochrome $c$ accumulation in the cytoplasm (Figure 6). A small amount of cytochrome $c$ is present in the cytoplasmic fraction of the control promastigotes, but cytochrome $c$ is abundant in the cytoplasmic fraction of CPT-treated cells. In addition, treatment of cells with NAC $(20 \mathrm{mM})$, SB $(20 \mathrm{mM})$ and BHT $(20 \mathrm{mM})$ separately prior to CPT treatment prevented cytochrome $c$ release. However, the release of cytochrome $c$ in the cytoplasm is not prevented when cells were pre-incubated with cyclosporin $\mathrm{A}(5 \mu \mathrm{M})$ prior to treatment with CPT. This proves that there is no involvement of a cyclosporin $A$ sensitive permeability transition pore in the collapse of mitochondrial membrane potential. To investigate the role of CED-3/CPP32 group of protease inhibitors in the release of cytochrome $c$ in cytosol, cells were treated with CED-3/ CPP32 group of protease inhibitor (VAD-fmk) before CPT treatment. Our experimental results show that these groups of

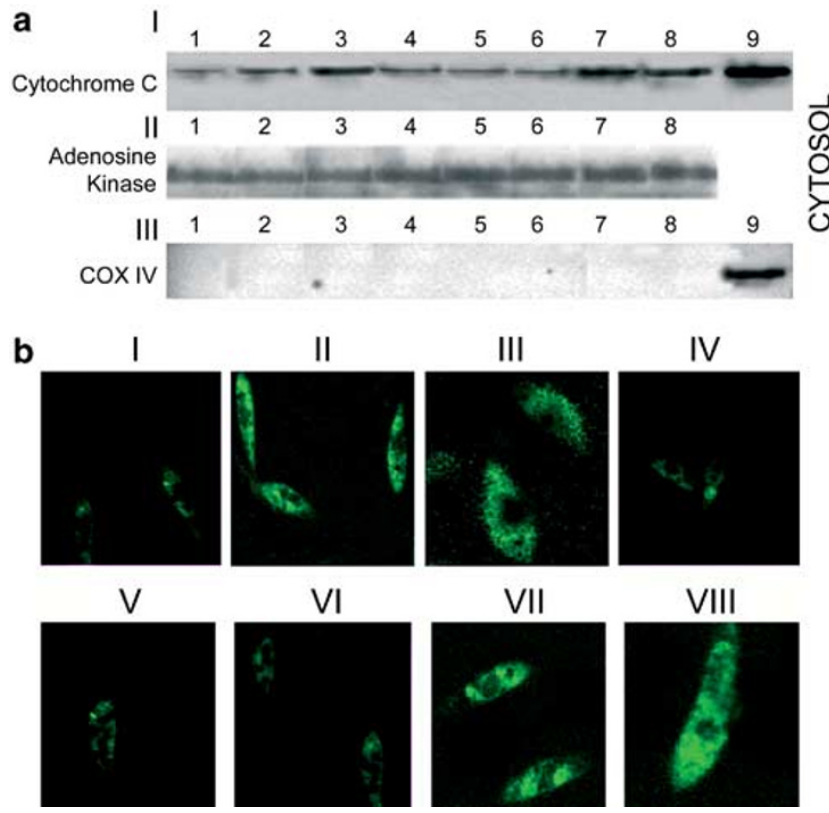

Figure 6 Determination of release of cytochrome $c$ in L. donovani. (a) Western blot analysis to detect the release of cytochrome $c$ into cytosol of differently treated cells (I). Lane 1, control cells; lane 2, cells treated with CPT for $3.5 \mathrm{~h}$; lane 3 , cells treated with CPT for $5 \mathrm{~h}$; lanes 4-8, treatment with NAC, SB, BHT, CED3/ CPP32 group of protease inhibitor and Cyclosporin A separately prior to treatment with CPT for $4.5 \mathrm{~h}$; and lane 9, total level of cytochrome $c$ in leishmanial cells. As loading controls cytosolic fractions from differently treated $L$. donovani promastigotes were analysed for the presence of adenosine kinase (II) and COX IV (III) by Western blotting. Lanes 1-8 of (II) and (III) are the same as lanes 1-8 of (I). Lane 9 of (III) represents the total level of COX IV in leishmanial cells. (b) Localization of cytochrome $c$ in treated and untreated cells through confocal microscopy. Cells treated with $0.2 \%$ DMSO (I), treatment with $5 \mu \mathrm{M} \mathrm{CPT}$ for $3.5 \mathrm{~h}$ (II) and for $5 \mathrm{~h}$ (III). Cells treated with NAC (IV), SB (V), BHT (VI), CED-3/CPP32 group of protease inhibitor (VAD-fmk) (VII) and cyclosporin A (VIII) prior to treatment with CPT for $4.5 \mathrm{~h}$. Pictures are representative of one of three similar results 
inhibitors do affect cytochrome $c$ release in the cytosol. As controls we have checked the presence of adenosine kinase (a constitutive cytosolic protein) and absence of COX IV (a mitochondrial protein) in the cytosol of $L$. donovani promastigotes treated with or without CPT.

\section{CPT causes activation of caspase-like proteases in cytosol, cleavage of PARP protein and externalization of phosphatidyl serine}

Many studies have demonstrated that the release of cytochrome $c$ from mitochondria into the cytosol leads to an activation of the caspase cascade. ${ }^{16}$ Caspase 3 is a member of CED-3/CPP32 group of proteases and caspase 9 is a member of the ICE family of proteases. To further substantiate the existence of these proteases in L. donovani, we carried out fluorometric assay of both CED3/CPP32 and ICE family of proteases using their specific substrates Asp-Glu-Val-Asp7-amino-4-trifluoromethyl coumarin (DEVD-AFC) and LeuGlu-His-Asp-7-amino-4-methyl coumarin (LEHD-AMC), respectively. The activities were measured in terms of liberation of AFC and AMC from their substrates. A significant increase in the activity of ICE group of proteases was observed after treatment with CPT for $3 \mathrm{~h}$ compared to $0.2 \%$ DMSO-treated control cells (Figure 7a). A similar increase in the activity of CED3/CPP32 group of proteases was also observed after $3.5 \mathrm{~h}$ treatment with CPT (Figure $7 \mathrm{~b}$ ). In the presence of specific inhibitor of these proteases (LEHD-CHO for ICE group and DEVD-CHO for CED3/CPP32 group), activities of these enzymes were inhibited.

PARP [poly(ADP ribose) polymerase], an enzyme involved in DNA repair, is a preferential substrate for caspase $3 .^{30} \mathrm{We}$ determined the extent of PARP cleavage by immunoblot analysis of the PARP cleavage products. Figure 7c shows PARP cleavage in control cells and cells treated with CPT. PARP protein $(78 \mathrm{kDa})$ generates a $63 \mathrm{kDa}$ cleaved fragment upon treatment of cells with CPT for $4.0 \mathrm{~h}$. However, the cleavage of this PARP protein did not occur when cells were pretreated with the CED-3/CPP32 group of protease inhibitor VAD-fmk.

Induction of apoptosis causes the externalization of phosphatidyl serine on the surface of apoptotic cells, ${ }^{31}$ which was detected by using annexin $\mathrm{V}$ that binds with exposed phosphatidylserine of apoptotic cells in a $\mathrm{Ca}^{2+}$-dependent manner. This was observed in both extracellular promastigotes and intracellular amastigotes in infected cells after treatment with CPT (Figure 7d). Treatment of promastigote cells with $10 \mu \mathrm{M}$ protease inhibitor VAD-fmk plus CPT causes disappearance of green rings around their cell membrane. This observation supports that the appearance of PS on outer leaflet apparently requires caspase-like protease activation in leishmanial promastigote cells.

\section{Activation of caspase-like proteases causes fragmentation of genomic DNA}

During apoptosis the cleavage patterns of genomic DNA are typical of internucleosomal DNA digestion by an endogenous nuclease, which is considered as a hallmark of apoptotic cell
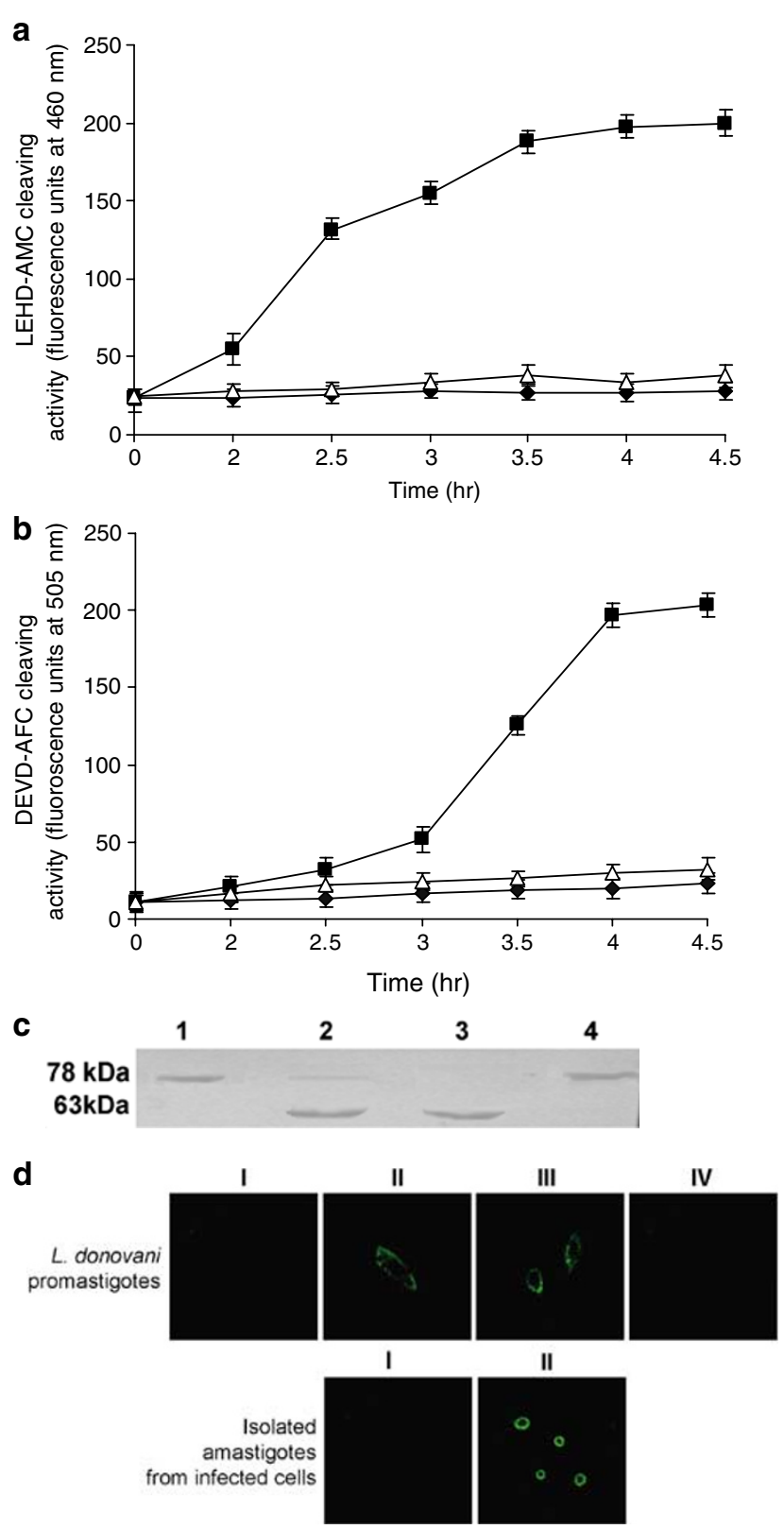

Figure 7 Determination of caspase-like protease activity and its downstream effects in the presence and in the absence of CED3/CPP32 group of protease inhibitor (a) Activation of ICE group of proteases in the cytosol of leishmanial cells was measured after treatment with $5 \mu \mathrm{M} \mathrm{CPT}(\boldsymbol{\square}), 0.2 \%$ DMSO alone ( $)$ and with LEHD-CHO to CPT-treated cells $(\triangle)$. (b) Activation of CED3/CPP32 group of protease inside leishmanial cell was measured after treatment with $5 \mu \mathrm{M}$ CPT ( ), $0.2 \%$ DMSO alone ( ) and with DEVD-CHO inhibitor to CPT-treated cells $(\triangle)$. Results are mean \pm S.D. from three independent experiments. (c) Western blot analysis to detect the cleavage of full-length PARP protein after treatment with $0.2 \%$ DMSO alone (1) with $5 \mu \mathrm{M} \mathrm{CPT}$ for $4 \mathrm{~h}$ (2) and $5 \mathrm{~h}$ (3) and with CED3/ CPP32 group of protease inhibitor (VAD-fmk) prior to treatment with CPT (4). (d) Externalization of PS residues was detected both in $L$. donovani promastigote and amastigote cells. (a) Annexin $V$ labelling of $L$. donovani promastigotes was measured after treatment with $0.2 \%$ DMSO alone (I), $5 \mu \mathrm{M} \mathrm{CPT}$ for $3 \mathrm{~h}$ (II) and $5 \mathrm{~h}$ (III) and treatment with CED3/CPP32 group of protease inhibitor (VAD-fmk) prior to treatment with CPT (IV), respectively. (b) Annexin V labelling of isolated amastigotes from $0.2 \%$ DMSO-treated (I) and $2.5 \mu \mathrm{M}$ CPT treated infected macrophages at $12 \mathrm{~h}(\mathrm{II})$, respectively. Pictures are representative of one of three similar results 


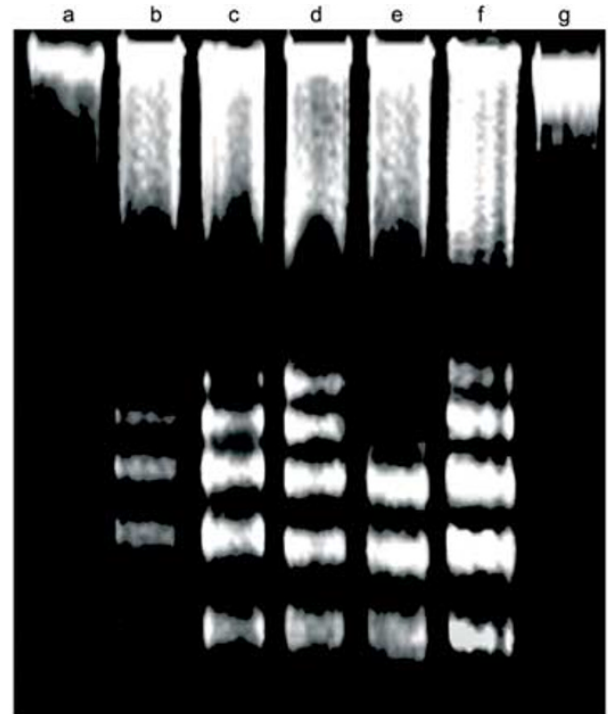

b

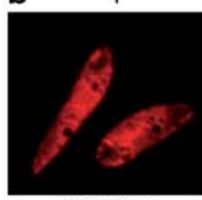

CONTROL

C

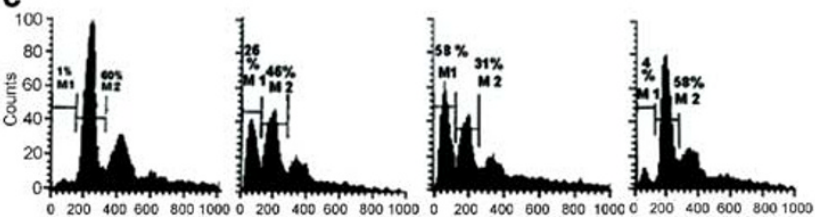

Figure 8 Fragmentation of genomic DNA in the presence and in the absence of CED-3/CPP32 group of protease inhibitor (VAD-fmk). (a) Genomic DNAs were isolated from $L$. donovani promastigotes after treatment with $0.2 \%$ DMSO alone (a) and $5 \mu \mathrm{M}$ CPT for $4 \mathrm{~h}$ (b) and $6 \mathrm{~h}$ (c). Lanes $\mathrm{d}$, e and f represent genomic DNAs isolated from $5 \mu \mathrm{M}$ CPT-treated promastigote cells of $L$. tropica, $L$. amazonensis and L. major. Genomic DNAs were also isolated after treatment with of CED-3/CPP32 group of protease inhibitor (VAD-fmk) prior to the treatment with CPT (lane g). (b) CPT-induced DNA cleavage was characterized in $L$. donovani promastigote cells by TUNEL assay. Nonapoptotic cells (I), cells after treatment with $5 \mu \mathrm{M} \mathrm{CPT}$ for $3.5 \mathrm{~h}$ (II) and $5 \mathrm{~h}$ (III) and with CED-3/CPP32 group of protease inhibitor (VAD-fmk) (IV). (c) Cell cycle arrest was analysed after treatment with $0.2 \%$ DMSO alone (I), $5 \mu \mathrm{M} \mathrm{CPT}$ for $2.0 \mathrm{~h}$ (II), $3.5 \mathrm{~h}$ (III) and with CED-3/CPP32 group of protease inhibitor, VAD-fmk prior to treatment with CPT for $3.5 \mathrm{~h}$ (IV), respectively. DNA fragmentation was quantified by measuring the sub $\mathrm{G} 0 / \mathrm{G} 1$ peak indicated by $\mathrm{M} 1$ and $\mathrm{G} 0 / \mathrm{G} 1$ peak indicated by $\mathrm{M} 2$.Gates were set to assess the percentage of dead ( $<2 n$ DNA), G0/G1 (2n DNA) and $\mathrm{S}+\mathrm{G} 2+n(>2 n \mathrm{DNA})$ cells. Pictures are representative of one of three similar results

death. ${ }^{32}$ CPT-induced formations of DNA ladder patterns are almost as clear as metazoan DNA ladder not only in $L$. donovani cells but also in $L$. tropica, $L$. amazonensis and $L$. major promastigote cells (Figure $8 \mathrm{a}$ ). In the presence of VADfmk, a CED3/CPP32 group of protease inhibitor, there is no DNA ladder formation, even after $10 \mathrm{~h}$ of drug treatment in $L$. donovani promastigotes. This further substantiates that some caspase-like proteases are involved in DNA ladder formation at the last stage of apoptosis of leishmanial cells.

The terminal deoxynucleotidyltransferase enzymemediated dUTP end labeling (TUNEL) assay detects the apoptosis at a single-cell level and thus permits a better evaluation of the apoptotic cell fraction. Control cells containing intact genomic DNA appears red due to staining with PI, whereas a considerable number of apoptotic cells coloured green when cells treated with CPT for $3.5 \mathrm{~h}$ and $5 \mathrm{~h}$. Approximately $80 \%$ of cells lose condensed nuclei and become TUNEL positive compared to control cells during treatment with CPT. In the presence of VAD-fmk, fragmentation of genomic DNA is inhibited and is not labelled with fluorescein (Figure 8b).

The cell cycle distribution was analysed by Flow Cytometry following treatment with CPT for different time periods (Figure 8c). In control cells the G1, S and G2 + M population remains almost same throughout the experiment. CPT caused $L$. donovani promastigotes to remain at resting $\mathrm{GO} /$ G1 phase $(26 \%)$ and inhibits their entry into the $S$ phase. The major alteration in DNA content resulted from the degradation of cellular DNA by the activation of endogenous nucleases during apoptosis. This is confirmed by the percentage of apoptotic cells that is increased to the extent of $58 \%$ after $3.5 \mathrm{~h}$ treatment with CPT. However, in the presence of VAD-fmk, the number of apoptotic cells decreases significantly to the extent of $4 \%$ and almost become same as control.

\section{Discussion}

In this study, we show that the leishmanicidal effect of CPT seems to be the consequence of the induction of a PCD both in intracellular amastigotes and extracellular promastigotes form of leishmanial cells. The typical aspect of apoptosis was demonstrated with $L$. donovani promastigote cells during treatment with 'topo I poison' CPT. Previous studies have shown that CPT treatment promotes stabilization of the cleavable complex with both nuclear as well as kinetoplast DNA. ${ }^{23}$ Very little is known about the signalling pathway downstream of the formation of cleavable complex, which ultimately leads to increase in the number of apoptotic cells. In the present study, CPT-induced cytotoxic lesion inside leishmanial cells appears to inhibit the mitochondrial respiration, which is followed by an increase in mitochondrial membrane potential. This result is reminiscent of those of other investigators, who concluded that an early increase in $\Delta \psi_{\mathrm{m}}$ is a common event in the process of apoptosis in a variety of cells with different proapoptotic stimuli including CPT. ${ }^{33-35}$ We have shown that mitochondrial hyperpolarization in leishmanial cells is prevented by treatment with oligomycin prior to the treatment with CPT. From this result it is confirmed that $F_{0}-F_{1}$ ATPase-like protein in leishmanial cells plays a very important role in the increase of mitochondrial membrane potential. The role of this protein for the increase in mitochondrial membrane potential is well established in mammalian cells. It is known that mitochondrial membrane hyperpolarization is dependent on the utilization of glycolytic ATP by oligomycin-sensitive F0-F1 ATPase in the reverse mode and at the same time other transporters are also acting in the reverse mode ${ }^{36,37}$ This hyperpolarization has been interpreted as being independent or part of the apoptotic process in mammalian cells. ${ }^{33,38}$ In case of leishmanial cells, mitochondrial hyperpolarization occurred before the increase 
in the number of apoptotic cells. This proves that increase in mitochondrial membrane potential is a preapoptotic event during treatment with CPT. But the significance of this event in PCD of leishmanial cells remains unclear. This earlier event is followed by mitochondrial depolarization, which is an irreversible commitment of the cell to apoptosis after administration of several apoptotic stimuli to different cell types.

In the present study, a nonoxidant CPT causes an increase in the level of ROS inside cells, which is responsible for the collapse of mitochondrial membrane potential in leishmanial cells. During $30 \%$ inhibition of $\mathrm{O}_{2}$ consumption, an initial rise of superoxide anion was observed, which consequently leads to an increase in the level of hydroxyl radicals through the generation of $\mathrm{H}_{2} \mathrm{O}_{2}$. Endogenous ROS causes an increase in lipid peroxide levels after $2 \mathrm{~h}$ of drug treatment. This increase in the level of lipid peroxidation causes the loss of mitochondrial membrane potential, observed after treatment with CPT for $2.5 \mathrm{~h}$. These results are consistent with those of other investigators, who concluded that lipid peroxidation and oxidative stress together may impair a variety of intra- and extramitochondrial membrane transport systems that may contribute to apoptosis. ${ }^{28,38}$ In mammalian cells, an increase in cellular ROS production has been observed in an apoptotic process triggered by various stimuli, ${ }^{33,39,40}$ and has been claimed to be responsible for the depolarization of $\Delta \psi_{\mathrm{m}}$ and subsequent cell death. ${ }^{33,39,41}$ Furthermore, some authors suggest that ROS generation precedes caspase activation, ${ }^{33,38}$ whereas others claim that it is a consequence. ${ }^{39}$ Very few studies have reported a detailed time course for the release of ROS inside cells, which is closely associated with apoptotic cell death. ${ }^{33}$ In CPT-mediated PCD of leishmanial cells, it is important to mention that the kinetics of ROS generation has reached maximum before apoptotic cell death. Our result is consistent with sodium fluoride (NaF)-mediated apoptosis of HL-60 cells where the levels of ROS are elevated just after $3 \mathrm{~h}$ of exposure whereas the membrane potential is lost after $8 \mathrm{~h}$ of drug treatment. ${ }^{29}$

One of the most important cellular defences against intracellular oxidative stress is GSH, which plays a critical role in mediating apoptosis in eukaryotes including leishmanial cells. A decrease in GSH level causes an increase in the number of CPT-induced DNA-protein crosslinks, indicating that GSH affects the mechanism of action of CPT. ${ }^{42}$ The actual mechanism by which GSH exerts its influence in leishmanial cells is yet to be explored.

CPT induces a concentration-dependent increase in the number of apoptotic cells whose onset is always subsequent to depolarization of $\Delta \psi_{\mathrm{m}}$. Collapse in $\Delta \psi_{\mathrm{m}}$ is closely associated with release of cytochrome $c$ into the cytoplasm of CPT-treated cells. We have also shown that the release of cytochrome $c$ is insensitive to Cyclosporin A (permeability transition pore (PTP) blocker) but treatment with different antioxidants prevents the loss of $\Delta \psi_{\mathrm{m}}$ and subsequent release of cytochrome $c$ from mitochondria. From this study, it is well established that the loss of $\Delta \psi_{\mathrm{m}}$ is mainly due to oxidative stress, which leads to the release of cytochrome $c$ from mitochondria. Multiple lines of evidences have established that caspase-like proteases play important roles in the apoptotic cascade of unicellular kinetoplastid parasites after induction of different stimuli. ${ }^{19,43}$ Although very little is known about the total number of caspase-like proteases present in leishmanial cells and of their specificity to cleave the specific substrates, the activation of CED3/CPP32 group of proteases is well established in leishmanial cells. ${ }^{19}$ In our study, we show that ICE family of proteases was activated before the activation of CED3/CPP32 group of proteases during treatment with CPT. So the possibility of the presence of caspase 9- and caspase 3-like proteases in leishmanial cells cannot be ruled out. In the presence of CED3/CPP32 group of protease inhibitor (VAD-fmk), known downstream events of caspase 3like protease activation such as PARP cleavage, DNA fragmentation and PS externalization were prevented, which suggests the involvement of CED3/CPP32 group of protease in apoptosis of leishmanial cells.

In mammalian cells, collisions between progressing DNA replication forks and CPT-mediated formation of cleavable complexes transform DNA nicks into double-strand breaks, which are recognized by the cell as lethal lesions. ${ }^{44}$ Such lesions, most likely via induction of tumour suppressor p53 and proapoptotic Bax proteins initiate the apoptotic execution pathway that starts in the mitochondria. In this context, it should be noted that HL-60 cells are p53 negative but induces apoptosis during treatment with CPT through mitochondrial pathway. ${ }^{45}$ Along this pathway mitochondrial membrane become permeabilized and cytochrome $c$ is released into the cytosol, where it associates with Apaf- 1 to form a scaffold, by which caspase 9 is activated. This in turn activates downstream caspases. ${ }^{14,16}$ The induction of apoptosis in mammalian cells also varies depending on the cell type and strength of CPT. For example, in Jurkat cells $10 \mu \mathrm{M}$ of CPT for $6 \mathrm{~h},{ }^{34}$ in HL-60 cells $5 \mu \mathrm{M}$ of CPT for $6 \mathrm{~h},{ }^{45}$ in U937 cells $10 \mu \mathrm{M}$ of CPT for $4 \mathrm{~h}^{31}$ and in HT-29 cells $8 \mu \mathrm{M}$ of CPT for $24 \mathrm{~h}^{46}$ are sufficient to induce apoptosis. Compared to mammalian cells, $80 \%$ of $L$. donavani promastigotes show apoptotic cell death at $5 \mu \mathrm{M}$ of CPT for $6 \mathrm{~h}$. Also, mitochondrial hyperpolarization and ROS formation inside $L$. donovani promastigotes play significant roles in modulating the response of the parasite to topoisomerase I poison CPT. Like other mammalian systems, the release of cytochrome $c$, activation of caspase-like proteases and PARP cleavage are common events in PCD of $L$. donovani promastigote cells. The occurrence of these molecular events provides substantial evidences in support of the fact that the PCD machinery in unicellular organisms like kinetoplastids may have evolved through a process of horizontal gene transfer or evolutionary convergence.

Recently, it was reported that CPT-mediated formations of topoisomerase I-DNA covalent complexes are degraded via $26 \mathrm{~S}$ proteosome pathway, which is followed by transcription coupled repair to recover the normal cell from death. ${ }^{47}$ In contrast, most tumour cells are defective in topoisomerase I degradation and unable to recover from transcriptional arrest. $L$. donovani is a unicellular protozoan parasite and it undergoes apoptosis-like death during treatment with CPT. This divergent response of the parasite to topoisomerase I poison CPT compared to the host cell response could be exploited to limit their growth and treat the disease they cause. In addition, the molecular characterization of effector molecules like PARP protein, which are critical for CPT-mediated apoptosis of leishmanial cells, provide opportunities for screening and designing of novel therapeutic agents against this parasite. 


\section{Materials and Methods}

\section{Parasite culture and maintenance}

Leishmania strain AG 83 promastigotes were grown at $22^{\circ} \mathrm{C}$ in M199 liquid media supplemented with $10 \%$ fetal calf serum. Different species of Leishmania (L. tropica, L. amazonensis and L. major) were also grown under the same culture condition.

\section{Drug solutions}

CPT was dissolved in 100\% dimetheyl sulphoxide (DMSO) at $20 \mathrm{mM}$ concentration and stored at $-20^{\circ} \mathrm{C}$. SB, Mannitol, NAC and BHT were dissolved in $100 \%$ DMSO at $50 \mathrm{mM}$ concentration and stored at $-20^{\circ} \mathrm{C}$

\section{Culture, differentiation and infection of U937 cells}

The human promonocytic cell line U937 was obtained from ATCC (American Type Culture Collection). Cells were cultured in suspension in stationary cell-culture flasks in RPMI 1640 medium (Life Technologies) supplemented with $10 \%$ FCS, penicillin and streptomycin at $37^{\circ} \mathrm{C}$ in a humidified atmosphere of $5 \% \mathrm{CO}_{2}$. Prior to infection with $\mathrm{L}$. donovani, U937 cells were cultured for $18 \mathrm{~h}$ in the presence of PMA $(10 \mathrm{ng} / \mathrm{ml}$; Sigma), rendering the cells adherent and capable of phagocytosis of $L$. donovani promastigotes. ${ }^{48}$ PMA-differentiated U937 cells were infected with freshly transformed promastigotes of $L$. donovani at a cell-to-parasite ratio of $1: 10$. After incubation at $37^{\circ} \mathrm{C}$ for the $18 \mathrm{~h}$, noningested parasites were removed by vigorous washing with RPMI three times. The infected macrophages were treated with $2.5 \mu \mathrm{M} \mathrm{CPT}$ and $0.2 \%$ DMSO separately for $12 h^{49}$

\section{Purification of amastigotes from infected macrophages}

Amastigotes were purified from $L$. donovani-infected U937 cells as described by Chang and Hendricks. ${ }^{50}$ Briefly, infected macrophages were harvested and were subjected to a process of freezing in liquid $\mathrm{N}_{2}$ and subsequent thawing at $37^{\circ} \mathrm{C}$ for five cycles. Then total suspension was centrifuged at $400 \times g$ for $5 \mathrm{~min}$. The pellet was discarded and the suspension was loaded on percoll gradient to isolate amastigotes from macrophages. ${ }^{51}$ The purity was verified under phase contrast microscope.

\section{Cytotoxicity assay}

Cytotoxicity of the drug was estimated by microscopic counting of viable parasites by trypan blue exclusion method after treatment with CPT.

\section{Study of dyskinetoplastidy by confocal microscopy}

Smears of drug-treated $L$. donovani $A G 83$ promastigotes $\left(2.5 \times 10^{6} / \mathrm{ml}\right)$ were assessed for dyskinetoplastic cells by ethidium bromide staining $(0.1 \mu \mathrm{g} / \mathrm{ml}$ in $1 \times$ phosphate-buffered saline containing $10 \%$ glycerol). Cells were viewed with a TCS-SP Leica confocal microscope system equipped with a krypton-argon mixed laser.

\section{Study of parasite ultrastructure by TEM}

Transmission electron microscopy (TEM) was carried out with both CPTtreated and -untreated cells according to RoyChoudhury et $a l^{52}$ Sections were cut with a Du-point diamond knife in an LKB Ultramicrotome, stained on copper grids with uranyl acetate and lead acetate for 10-15 min, respectively, and examined under JEOL $100 \mathrm{CX}$ TEM. ${ }^{53}$

\section{Measurement of oxygen consumption}

L. donovani AG83 promastigotes $\left(2.5 \times 10^{6}\right)$ were treated with $5 \mu \mathrm{M} \mathrm{CPT}$ for different time periods. Cells were harvested and washed with respiration buffer ( $50 \mathrm{mM}$ sucrose, $145 \mathrm{mM} \mathrm{KCl}, 5 \mathrm{mM} \mathrm{NaCl}, 1 \mathrm{mM}$ EDTA, $1 \mathrm{mM} \mathrm{MgCl} 2$ and $10 \mathrm{mM}$ sodium-phosphate buffer, $\mathrm{pH}$ 7.4) and finally suspended in the same buffer. Oxygen uptake was determined with a Clarke type oxi-electrode ${ }^{54}$ having a cell capacity of $2 \mathrm{ml}$. The oxygen electrode was calibrated with air-saturated water containing sodium metabisulphite. Oxygen consumption was completely suppressed by $1 \mathrm{mM}$ $\mathrm{KCN}$ and was taken to be a direct measure of mitochondrial respiration.

\section{Measurement of generation of superoxide radical}

To monitor the level of superoxide anion, cells of different treated groups along with control cells were washed with $1 \times$ PBS (pH 7.4) and then suspended in $100 \mu \mathrm{l}$ of the same buffer. In all, $10 \mu \mathrm{l}$ of each suspension was added to $1 \mathrm{ml}$ of reaction mixture containing $50 \mathrm{mM}$ sodium carbonate, $50 \mu \mathrm{M}$ NBT, $0.1 \mathrm{mM}$ EDTA and $0.5 \%$ Triton X-100. In a parallel set of reactions, $100 \mathrm{nM} \mathrm{SOD}$ was added to each of the reaction mixtures prior to addition of respective cell suspension. The reduction of NBT to blue formazan and the inhibition by SOD indicates the generation of super oxide radical. ${ }^{25}$ Spectrophotometric analysis was carried out at $560 \mathrm{~nm}$

\section{Measurement of hydroxyl radical}

The formation of hydroxyl radical in leishmanial cells was measured according to Babbs and Steiner. ${ }^{55,56}$ Briefly, cells $\left(2.5 \times 10^{6}\right)$ were suspended in M199 media containing 2\% DMSO for $1 \mathrm{~h}$ prior to treatment with $5 \mu \mathrm{M}$ CPT for different time periods. Cells were washed with $1 \times$ PBS and homogenized. Proteins were precipitated by adding $1 \mathrm{ml}$ of $10 \mathrm{~N}$ $\mathrm{H}_{2} \mathrm{SO}_{4}$. After centrifugation, the $\mathrm{pH}$ of the supernatant was brought to neutral by adding $10 \mathrm{~N} \mathrm{NaOH}$. To this supernatant, $0.2 \mathrm{ml}$ of $10 \mathrm{~N} \mathrm{H}_{2} \mathrm{SO}_{4}$ was added along with $2 \mathrm{ml}$ of toluene : butanol solution (3:1). The mixture was vortexed and centrifuged for $5 \mathrm{~min}$ at $500-1000 \mathrm{rpm}$. The upper layer was discarded and to the lower layer $4 \mathrm{ml}$ of butanol (saturated with $1 \mathrm{~N}$ $\mathrm{H}_{2} \mathrm{SO}_{4}$ ) was added, vortexed and centrifuged as above. The upper butanol layer was added to sodium-acetate buffer in a separate tube and centrifuged as above. The lower layer was taken and added to fast blue BB salt $(40 \mathrm{mM})$ solution and was kept in the dark for $20 \mathrm{~min}$. Spectrophotometric analysis was carried out at $425 \mathrm{~nm}$.

\section{Measurement of total fluorescent lipid peroxidation product}

Treated and untreated cells were pelleted down and washed twice with $1 \times$ PBS. The pellet was dissolved in $2 \mathrm{ml}$ of $15 \%$ SDS-PBS solution. The fluorescence intensities of the total fluorescent lipid peroxidation products were measured with excitation at $360 \mathrm{~nm}$ and emission at $430 \mathrm{~nm}^{57}$ and expressed as relative fluorescence units with respect to quinine sulphate ( $1 \mathrm{mg} / \mathrm{ml}$ in $0.5 \mathrm{M} \mathrm{H}_{2} \mathrm{SO}_{4}$ ).

\section{Measurement of GSH level}

GSH level was measured by monochlorobimane (MCB) dye that gives a blue fluorescence when bound to glutathione. ${ }^{58} \mathrm{~L}$. donovani promasti- 
gotes $\left(2.5 \times 10^{6}\right.$ cells) were treated with or without CPT at different times. Cells were then pelleted down and lysed by cell lysis buffer according to the manufacturer's protocol (Apo Alert ${ }^{\mathrm{TM}}$ glutathione assay kit). Cell lysates were incubated with $\mathrm{MCB}(2 \mathrm{mM})$ for $3 \mathrm{~h}$ at $37^{\circ} \mathrm{C}$. The decrease in glutathione levels in the extracts of nonapoptotic and apoptotic cells were detected by fluorometer with $395 \mathrm{~nm}$ excitation and $480 \mathrm{~nm}$ emission wavelengths.

\section{Measurement of mitochondrial membrane potential}

Mitochondrial membrane potential was measured using BD mitosensor reagent following the protocol of the manufacturer. Briefly, cells after different treatment were harvested and washed with $1 \times$ PBS. Cells were then incubated at $37^{\circ} \mathrm{C}$ in $5 \% \mathrm{CO}_{2}$ incubator for $1 \mathrm{~h}$ with a final concentration of $\mathrm{BD}$ mitosensor reagent at $5 \mu \mathrm{g} / \mu \mathrm{l}$. Cells were then analysed by flow-cytometry as well as by fluorescence measurements. The ratio of the reading at $590 \mathrm{~nm}$ to the reading at $530 \mathrm{~nm}(590: 530$ ratio) was considered as the relative $\Delta \psi_{\mathrm{m}}$ value. $^{18}$

\section{Detection of cytochrome $c$ release}

\section{Western blotting}

Treated and untreated cells were harvested and washed twice with $1 \times$ PBS, suspended in cell fractionation buffer (Apo Alert ${ }^{\mathrm{TM}}$ cell fractionation kit) and homogenized. After the separation of cytosolic and mitochondrial fraction, $50 \mu \mathrm{g}$ each of cytosolic proteins were separated on $12 \%$ SDSPAGE and immunoblotted with the rabbit polyclonal cytochrome $c$ antibody. The same amounts of cytosolic fractions $(50 \mu \mathrm{g})$ were also immunoblotted with rabbit polyclonal antibody raised against $L$. donovani adenosine kinase and cytochrome $c$ oxidase subunit IV (COX IV) as loading controls. Alkaline phosphatase conjugated secondary antibody was used and protein band were visualized by NBT and BCIP colour reaction.

\section{Immunofluorescence microscopy}

Treated and untreated cells were fixed on Poly-L-Lysine-coated coverslips. Cells were then washed twice with $1 \times$ PBS, followed by permeabilization in $0.2 \%(\mathrm{~V} / \mathrm{V})$ Triton $\mathrm{X}-100$ in PBS for $15 \mathrm{~min}$ at $4^{\circ} \mathrm{C}$. Cells were incubated in blocking buffer ( $3 \% \mathrm{BSA}$ in PBS) for $90 \mathrm{~min}$ at $4{ }^{\circ} \mathrm{C}$. Rabbit polyclonal cytochrome $C$ antibody (diluted $1 / 100$ in blocking buffer) was added to these cells. FITC conjugated secondary antibody was used to visualize the release of cytochrome $c$ by TCS-SP Leica confocal microscopy.

\section{Determination of caspase-like protease activity}

L. donovani promastigotes $\left(2.5 \times 10^{6}\right)$ were treated with or without CPT for different time periods. Cells were then pelleted and lysed by cell lysis buffer according to the manufacturer's protocol (Apo Alert ${ }^{\mathrm{TM}}$ caspase assay kit). Cell lysates were incubated with respective caspase buffers to detect CED3/CPP32 and ICE group of protease activities. Individual fluorogenic peptide substrates (DEVD-AFC for CED3/CPP32 and LEHDAMC for ICE group of proteases) at $100 \mu \mathrm{M}$ and $1 \times$ reaction buffer containing $100 \mathrm{mM}$ DTT were added to corresponding cell lysates. In a parallel set of reactions, $1 \mu \mathrm{l}$ of respective ICE and CED-3/CPP32 group of protease inhibitors was added to the reaction prior to the addition of cell lysates. AFC and AMC release were measured after incubating these samples at $37^{\circ} \mathrm{C}$ for $2 \mathrm{~h}$ by a fluorometer with $400 \mathrm{~nm}$ excitation and $500 \mathrm{~nm}$ emission and $380 \mathrm{~nm}$ excitation and $460 \mathrm{~nm}$ emission, respectively.

\section{Double staining with annexin $\mathrm{V}$ and propidium iodide}

Externalization of phosphatidylserine on the outer membrane of untreated and CPT-treated promastigotes was measured by the binding of annexin V-FITC and PI using an annexin V-FLUOS staining kit (Roche Diagnostics). Cells were visualized with TCS-SP Leica confocal microscope through dual FITC/PI filter set. To evaluate the CPT-induced apoptosis of amastigotes in infected U937 cells, cells were infected with $L$. donovani promastigotes and treated with CPT. Amastigotes were purified from infected cells and stained with annexin $\mathrm{V}$ and $\mathrm{PI}$ as before. Total cells versus only annexin $\mathrm{V}$ labelled cells were calculated and data were expressed as percentage of apoptotic cells. It should be noted that 100 cells per group with identical morphology were calculated for each condition.

\section{Assay of PARP cleavage}

Cell lysates were prepared from CPT-treated and untreated cells, separated on $12.5 \%$ SDS-PAGE and subjected to Western blot analysis as described previously. Anti-PARP monoclonal antibody (purified mouse anti-human PARP) was diluted to 1000 times and alkaline phosphatase conjugated secondary antibody was used to visualize the reactive band by NBT and BCIP colour reaction.

\section{DNA ladder}

Genomic DNAs from exponentially growing $L$. amazonensis, $L$. tropica, $L$. major and $L$. donovani AG83 promastigotes $\left(2.5 \times 10^{6}\right)$ treated with or without CPT were isolated with an apoptotic DNA ladder kit (Roche Biochemicals). In another set, $L$. donovani promastigote cells were incubated with $10 \mu \mathrm{M}$ VAD-fmk, a CED3/CPP32 group of protease inhibitor for $1 \mathrm{~h}$ followed by treatment with $5 \mu \mathrm{M} \mathrm{CPT}$ for 4 and $6 \mathrm{~h}$. DNAs were electrophoresed in $1.5 \%$ agarose gel at $75 \mathrm{~V}$ for $2 \mathrm{~h}$, stained with ethidium bromide and photographed under UV-illumination.

\section{TUNEL assay}

To know the alterations in DNA content in the nucleus, treated and untreated $L$. donovani promastigote cells were fixed with $2 \%$ paraformaldehyde and incubated with $0.2 \%$ Triton $X-100$ for $5 \mathrm{~min}$ for permeabilization and layered with TdT reaction mixture containing FITClabelled dUTP for $1 \mathrm{~h}$ at $37^{\circ} \mathrm{C}$ according to the manufacturer's protocol (Apo Alert ${ }^{\mathrm{TM}}$ DNA fragmentation assay kit). Cells were stained with propidium iodide and visualized with TCS-SP Leica confocal microscope through dual pass FITC/PI filter set.

\section{Cell cycle analysis}

For flow cytometry analysis of DNA content, exponentially grown $L$. donovanipromastigote cells $\left(2.6 \times 10^{6}\right)$ were treated with $5 \mu \mathrm{M} \mathrm{CPT}$ in the presence or absence of CED-3/CPP32 group of protease inhibitor (VAD$\mathrm{fmk}$ ). Cells were then harvested and washed three times with $1 \times$ PBS, fixed in $45 \%$ ethanol (diluted in $1 \times$ PBS), treated with $500 \mu \mathrm{g} / \mathrm{ml} \mathrm{RNAse}$ $A$ and then suspended in $0.5 \mathrm{M}$ sodium citrate containing $69 \mu \mathrm{M} \mathrm{PI}$. These samples were analysed through flow cytometry after keeping them in the dark for $45 \mathrm{~min}$.

\section{Statistical analysis}

Data are expressed as mean \pm S.E. unless mentioned. Comparisons were made between different treatments using unpaired Student's $t$-test. 


\section{Acknowledgements}

This paper is dedicated to the memory of Professor AN Bhaduri, former director and coordinator of the Leishmania Programme of this institute. We thank Professor S. Bhattacharya, the Director of our institute, for his interest in this work. We are grateful to Drs. Ranjan Bhadra, Alok Dutta and Ranajit Banerjee of Indian Institute of Chemical biology, Kolkata and Professor Sasanka Chakraborti of Dr. BC Roy Postgraduate Institute of basic Medical sciences, Department of Biochemistry for their valuable suggestions and expertise. We also acknowledge Mr. Sailen Dey for his help with electron microscopy. NS is supported by a Senior Research Fellowship from the Council of Scientific and Industrial Research, Government of India.

\section{References}

1. Liu LF (1994) DNA Topoisomerases: Biochemistry and Molecular Biology. Advances in Pharmacology, Vol. 29A (New York: Academic Press)

2. Sutcliffe JA, Gootz TD and Barrett JF (1989) Biochemical characteristics and physiological significance of major DNA topoisomerases. Antimicrob. Agents Chemother. 33: 2027-2033

3. Wang JC (1991) DNA topoisomerases: why so many? J. Biol. Chem. 266: 6659-6662

4. Nelson EM, Tewey KM and Liu LF (1984) Mechanism of antitumor drug action: poisoning of mammalian DNA topoisomerase II on DNA by $4^{\prime}-(9$ acridinylamino)-methanesulfon-m-anisidide. Proc. Natl. Acad. Sci. 81: 13611365

5. Hsiang YH, Hertzberg R, Hecht S and Liu LF (1985) Camptothecin induces protein-linked DNA breaks via mammalian DNA topoisomerase I. J. Biol. Chem. 260: 14873-14878

6. Tsao YP, D'Arpa P and Liu LF (1992) The involvement of active DNA synthesis in camptothecin-induced $\mathrm{G} 2$ arrest: altered regulation of p34cdc2/cyclin B. Cancer Res. 52: 1823-1829

7. Ryan AJ, Squires S, Strutt HL, Evans A and Johnson RT (1994) Different fates of camptothecin-induced replication fork-associated double-strand DNA breaks in mammalian cells. Carcinogenesis 15: 823-828

8. Nelson WG and Kastan MB (1994) DNA strand breaks: the DNA template $q$ alterations that trigger p53-dependent DNA damage response pathways. Mol. Cell Biol. 14: 1815-1823

9. Desai SD, Liu LF, Vazquez-Abad D and D'Arpa P (1997) Ubiquitin-dependent destruction of topoisomerase $\mathrm{I}$ is stimulated by the antitumor drug camptothecin. J. Biol. Chem. 272: 24159-24164

10. Piret $B$ and Piette $J(1996)$ Topoisomerase poisons activate the transcription factor NF-kappaB in ACH-2 and CEM cells. Nucleic. Acids Res. 24: 4242-4248

11. Kerr JF, Wyllie AH and Currie AR (1972) Apoptosis: a basic biological phenomenon with wide-ranging implications in tissue kinetics. Br. J. Cancer 26 : 239-257

12. Halliwell B and Gutteridge JM (1990) Role of free radicals and catalytic metal ions in human diseases: an overview. Methods Enzymol. 186: 1

13. Mayes $P$ (1993) The pentose phosphate pathway and other pathways of hexose metabolism. In Harper's Biochemistry, Murray R, Granner D, Mayes P, Rodwell V, eds 23rd edn Norwalk CT: Appleton and Lange, 201 pp

14. Kluck RM, Bossy-Wetzel E, Green DR and Newmeyer DD (1997) The release of cytochrome $c$ from mitochondria: a primary site for $\mathrm{Bcl}-2$ regulation of apoptosis. Science 275: 1132-1136

15. Nomura K, Imai H, Koumura T, Kobayashi T and Nakagawa $Y(2000)$ Mitochondrial phospholipid hydroperoxide glutathione peroxidase inhibits the release of cytochrome $c$ from mitochondria by suppressing the peroxidation of cardiolipin in hypoglycaemia-induced apoptosis. Biochem J 351: 183-193

16. Zou H, Henzel WJ, Liu X, Lutschg A and Wang X (1997) Apaf-1, a human protein homologous to $C$ elegans CED-4 participates in cytochrome $C$ dependent activation of caspase-3. Cell 90: 405-413

17. Madeo F, Frohlich E and Frohlich KU (1997) A yeast mutant showing diagnostic markers of early and late apoptosis. J. Cell. Biol. 139: 729-734
18. Mukherjee SB, Das M, Sudhandiran G and Shaha C (2002) Increase in cytosolic $\mathrm{Ca} 2+$ levels through the activation of non-selective cation channels induced by oxidative stress causes mitochondrial depolarization leading to apoptosis-like death in Leishmania donovani promastigotes. J. Biol. Chem. 277: 24717-24727

19. Das M, Mukherjee SB and Shaha C (2001) Hydrogen peroxide induces apoptosislike death in Leishmania donovani promastigotes. J. Cell Sci. 114: 2461-2469

20. Chang KP and Dwyer DM (1976) Multiplication of a human parasite (Leishmania donovani) in phagolysosomes of hamster macrophages in vitro. Science 193: 678-680

21. Iwn MM, Jackson JE and Schuster BG (1994) Medicinal plants in the fight against leishmaniasis. Parasitol. Today 10: 65-68

22. Mittra B, Saha A, Chowdhury AR, Pal C, Mandal S, Mukhopadhyay S, Bandyopadhyay S and Majumder HK (2000) Luteolin, an abundant dietary component is a potent anti-leishmanial agent that acts by inducing topoisomerase II-mediated kinetoplast DNA cleavage leading to apoptosis. Mol. Med. 6: 527-541

23. Bodley AL and Shapiro TA (1995) Molecular and cytotoxic effects of camptothecin, a topoisomerase I inhibitor, on trypanosomes and Leishmania. Proc. Natl. Acad. Sci. 92: 3726-3730

24. Shapiro TA, Klein VA and Englund PT (1989) Drug-promoted cleavage of kinetoplast DNA minicircles. Evidence for type II topoisomerase activity in trypanosome mitochondria. J. Biol. Chem. 264: 4173-4178

25. Kono $Y$ (1978) Generation of superoxide radical during autooxidation of hydroxylamine and an assay for superoxide dismutase. Arch. Biochem. Biophys. 186: 189-195

26. Fairlamb AH and Cerami A (1992) Metabolism and functions of trypanothione in the Kinetoplastida. Annu. Rev. Microbiol. 146: 695-729

27. Kroemer G, Dallaporta B and Resche-Rigon M (1998) The mitochondrial death/ life regulator in apoptosis and necrosis. Annu. Rev. Physiol. 60: 619-642

28. Ma Y, Ogino T, Kawabata T, Li J, Eguchi K and Okada S (1999) Cupric nitrilotriacetate-induced apoptosis in HL-60 cells association with lipid peroxidation, release of cytochrome $C$ from mitochondria, and activation of caspase-3. Free Radicals Biol. Med. 27: 227-233

29. Anuradha CD, Kanno S and Hirano S (2001) Oxidative damage to mitochondria is a preliminary step to caspase-3 activation in fluoride-induced apoptosis in HL-60 cells. Free Radicals Biol. Med. 31: 367-373

30. Tewari M, Quan LT, O'Rourke K, Desnoyers S, Zeng Z, Beidler DR, Poirier GG Salvesen GS and Dixit VM (1995) Yama/CPP32 beta, a mammalian homolog of CED-3, is a CrmA-inhibitable protease that cleaves the death substrate poly(ADP-ribose) polymerase. Cell 81: 801-809

31. Yu A, Byers DM, Ridgway ND, McMaster CR and Cook HW (2000) Preferential externalization of newly synthesized phosphatidylserine in apoptotic U937 cells is dependent on caspase-mediated pathways. Biochim. Biophys. Acta 1487: 296-308

32. Compton MM (1992) A biochemical hallmark of apoptosis: internucleosomal degradation of the genome. Cancer Metastasis Rev. 11: 105-119

33. Banki K, Hutter E, Gonchoroff NJ and Perl A (1999) Elevation of mitochondrial transmembrane potential and reactive oxygen intermediate levels are early events and occur independently from activation of caspases in Fas signaling. J. Immunol. 162: 1466-1479

34. Joshi B, Li L, Taffe BG, Zhu Z, Wahl S, Tian H, Ben-Josef E, Taylor JD, Porter AT and Tang DG (1999) Apoptosis induction by a novel antiprostate cancer compound, BMD188 (a fatty acid-containing hydroxamic acid), requires the mitochondrial respiratory chain. Cancer Res. 59: 4343-4355

35. Sanchez-Alcazar JA, Ault JG, Khodjakov A and Schneider E (2000) Increased mitochondrial cytochrome $c$ levels and mitochondrial hyperpolarization precede camptothecin-induced apoptosis in Jurkat cells. Cell Death Differ. 7: 10901100

36. Khaled AR, Reynolds DA, Young HA, Thompson CB, Muegge K and Durum SK (2001) Interleukin-3 withdrawal induces an early increase in mitochondrial membrane potential unrelated to the $\mathrm{Bcl}-2$ family roles of intracellular $\mathrm{pH}, \mathrm{ADP}$ transport, and $F(0) F(1)$ ATPase. J. Biol. Chem. 276: 6453-6462

37. Beltran B, Quintero M, Garcia-Zaragoza E, O'Connor E, Esplugues JV and Moncada S (2002) Inhibition of mitochondrial respiration by endogenous nitric oxide: a critical step in Fas signaling. Proc. Natl. Acad. Sci. 99: 8892-8897 
38. Li PF, Dietz R and von Harsdorf R (1999) p53 regulates mitochondrial membrane potential through reactive oxygen species and induces cytochrome c-independent apoptosis blocked by Bcl-2. EMBO J. 18: 6027-6036

39. Johnson TM, Yu ZX, Ferrans VJ, Lowenstein RA and Finkel T (1996) Reactive oxygen species are downstream mediators of p53-dependent apoptosis. Proc. Natl. Acad. Sci. 93: 11848-11852

40. Um HD, Orenstein JM and Wahl SM (1996) Fas mediates apoptosis in human monocytes by a reactive oxygen intermediate dependent pathway. J. Immunol. 156: 3469-3477

41. Vander Heiden MG, Chandel NS, Williamson EK, Schumacker PT and Thompson CB (1997) Bcl-xL regulates the membrane potential and volume homeostasis of mitochondria. Cell 91: 627-637

42. Gamcsik MP, Kasibhatla MS, Adams DJ, Flowers JL, Colvin OM, Manikumar G, Wani M, Wall ME, Kohlhagen G and Pommier Y (2001) Dual role of glutathione in modulating camptothecin activity: depletion potentiates activity, but conjugation enhances the stability of the topoisomerase I-DNA cleavage complex. Mol. Cancer Ther. 1: 11-20

43. Lee N, Bertholet S, Muller J, Duncan R and Nakhasi HL (2002) Programmed cell death in the unicellular protozoan parasite Leishmania. Cell Death Differ. 9: 53-64

44. Liu LF, Duann P, Lin CT, D'Arpa P and Wu J (1996) Mechanism of action of camptothecin. Ann. NY Acad. Sci. 13: 44-49

45. Facompre M, Goossens JF and Bailly C (2001) Apoptotic response of HL-60 human leukemia cells to the antitumor drug NB-506, a glycosylated indolocarbazole inhibitor of topoisomerase 1. Biochem. Pharmacol. 61: 299310

46. Chauvier D, Morjani $H$ and Manfait M (2002) Ceramide involvement in homocamptothecin- and camptothecin-induced cytotoxicity and apoptosis in colon HT29 cells. Int. J. Oncol. 20: 855-863

47. Desai SD, Zhang H, Rodriguez-Bauman A, Yang JM, Wu X, Gounder MK, Rubin EH and Liu LF (2003) Transcription-dependent degradation of topoisomerase I-DNA covalent complexes. Mol. Cell Biol. 23: 2341-2350
48. Nandan D and Reiner NE (1995) Attenuation of gamma interferon-induced tyrosine phosphorylation in mononuclear phagocytes infected with Leishmania donovani: selective inhibition of signaling through Janus kinases and Stat1. Infect. Immun. 63: 4495-4500

49. Ray M, Gam AA, Boykins RA and Kenney RT (2000) Inhibition of interferongamma signaling by Leishmania donovani. J. Infect. Dis. 181: 1121-1128

50. Chang KP and Hendricks LD (1985) Leishmaniasis. (New York: Elsevier Science Publishers B.V.) pp 213-244

51. Sudhandiran G and Shaha C (2003) Antimonial-induced increase in intracellular $\mathrm{Ca} 2+$ through non-selective cation channels in the host and the parasite is responsible for apoptosis of intracellular Leishmania donovan amastigotes. J. Biol. Chem. 278: 25120-25132

52. Chowdhury AR, Mandal S, Goswami A, Ghosh M, Mandal L, Chakraborty D, Ganguly A, Tripathi G, Mukhopadhayay S, Bandyopadhyay S and Majumder HK (2003) Dihydrobetulinic acid induces apoptosis in Leishmania donovani by targeting DNA topoisomerase I and II: implications in antileishmanial therapy. Mol. Med. 9: 26-36

53. Majumder S, Dey SN, Chowdhury R, Dutta C and Das J (1998) Intracellular development of cholerphage $\phi 149$ under permissible and nonpermissible conditions: an electron microscopic study. Intervirology 29: 27-38

54. Santhamma KR and Bhaduri A (1995) Characterization of the respiratory chain of Leishmania donovani promastigotes. Mol. Biochem. Parasitol. 75: 43-53

55. Steiner MG and Babbs CF (1990) Quantitation of the hydroxyl radical by reaction with dimethyl sulfoxide. Arch. Biochem. Biophys. 278: 478-481

56. Babbs CF and Steiner MG (1990) Measurement of hydroxyl radical $(\mathrm{OH} \cdot)$ invivo. Methods Enzymol. 186: 137

57. Shimasaki $H$ (1994) Assay of fluorescent lipid peroxidation products. Methods Enzymol 233: 339-346

58. Jay AAW, Christine HC, Alan RB, Nancy KT, Patricia B, Cimity H and Charles GP (2000) Heterogeneity of Clara cell glutathione a possible basis for differences in cellular responses to pulmonary cytotoxicants. Am. J. Respir. Cell Mol. Biol. 23: 27-36 